\title{
Study of Calcium Concentration of Neera River at Sarola Bridge Shirval, Pune, Maharashtra
}

\author{
S. D. Jadhav"1 , M. S. Jadhav ${ }^{2}$ \\ ${ }^{1}$ Department of Basic Science \& Humanities, Bharati Vidyapeeth, Deemed to be University, \\ College of Engineering, Pune, Maharashtra, India \\ 2Department of Civil Engineering, Sinhgad Technical Education Society's, Sou. Venutai Chavan Polytechnic, \\ Pune, Maharashtra, India
}

\section{Article Info}

Volume 7, Issue 4

Page Number: 186-190

Publication Issue :

July-August-2020

\section{Article History}

Accepted : 05 Aug 2020

Published : 12 Aug 2020

\section{ABSTRACT}

Calcium is one of the important parameter for all the organisms which regulates the various physiological functions. The calcium ions along with magnesium ions contribute to the total hardness of water. Rivers generally contain 1-2 ppm calcium, but in some areas river may contain near about 100 $\mathrm{ppm}$ or more \% of calcium concentrations depending upon the surroundings and addition of the foreign bodies into the river water. To calculate the concentration of calcium in the present study of Neera river water, samples were collected and analyzed from eight sampling stations in the year 20182019. In the present work calcium concentration is having high range at some sampling stations in summer season.

Keywords : Calcium Concentration, Physiological Functions, Neera River, Summer session

\section{INTRODUCTION}

River water is the major source of drinking water in urban as well as rural part of India. Also, it is an important source of water for the agriculture and industrial sectors. Near about $70 \%$ of the fresh water, used by human being goes to agriculture (Mushini Venkatesh Subba Rao \& et.al. 2012). Agricultural runoff and industrial untreated waste effluents can bring about the considerable change in the river water quality. If the water is contaminated, then its quality cannot be restored by stopping the pollutants from the sources (Chatterjee S.N, et al. 2014, Hussain MF,
Ahmed I. 2002). Water is essential for any development activity and the availability of good quality of water for domestic and industrial use will help in fast development of the region (S. D. Jadhav, M. S. Jadhav, and R. W. Jawale, 2013). Due to rapid growth of population and industrialization there has been a tremendous increase in the demand for fresh water (Jaya Kalita Gogoi, 2016, Joshi DM, Kumar A, Agrawal N. 2009). Human health is threatened by most of the agricultural development activities like excessive use of fertilizers and unsanitary conditions (Katakwar M. 2014). Now a day's several places suffer from non-availability of water for domestic and 
industrial use due to it's over exploitation and improper waste disposal (Reddi Jhansilakshmi and E.U.B. 2014).

Devdhar dam is the origin place of Neera river. The river flows from its point of origin to the Veer dam and finally joins the Bhima river.

\section{METHODS AND MATERIAL}

Water samples were collected from seven sampling stations of river Neera at and near Sarola bridge in the year November 2018-June 2019 by following standard procedure (APHA1995, Trivedi R.K \& Goel P.K. 1984). These samples were collected in two liter plastic bottles, which were washed with distilled water before the collection of water samplers. Collected water samples were preserved safely by taking suitable precautions to avoid deterioration.

\section{OBSERVATION TABLE NO I}

\begin{tabular}{|c|c|c|c|c|c|c|c|c|c|}
\hline $\begin{array}{c}\text { Sampling } \\
\text { Stations }\end{array}$ & $\begin{array}{c}\text { Nov. } \\
2018\end{array}$ & $\begin{array}{c}\text { Dec. } \\
2018\end{array}$ & $\begin{array}{c}\text { Jan. } \\
2019\end{array}$ & $\begin{array}{c}\text { Feb. } \\
2019\end{array}$ & $\begin{array}{c}\text { Mar. } \\
2019\end{array}$ & $\begin{array}{c}\text { Apr. } \\
2019\end{array}$ & $\begin{array}{c}\text { May. } \\
2019\end{array}$ & $\begin{array}{c}\text { Jun. } \\
2019\end{array}$ & $\begin{array}{c}\text { Permissible } \\
\text { Limit }\end{array}$ \\
\hline 1 & 19 & 31 & 42 & 56 & 77 & 83 & 86 & 69 & \\
\cline { 1 - 9 } & 21 & 29 & 36 & 49 & 76 & 89 & 84 & 78 & \\
\hline 3 & 23 & 36 & 44 & 51 & 78 & 84 & 80 & 76 & \multirow{2}{*}{$200 \mathrm{mg} / 1$} \\
\hline 4 & 22 & 28 & 41 & 54 & 69 & 77 & 72 & 79 & \\
\hline 5 & 18 & 29 & 33 & 46 & 80 & 89 & 91 & 82 & \\
\hline 6 & 24 & 31 & 48 & 53 & 88 & 93 & 90 & 86 & \\
\hline 7 & 21 & 27 & 39 & 48 & 73 & 88 & 92 & 78 & \\
\hline
\end{tabular}

Fig 1. Graphical Presentation of Calcium Concentration

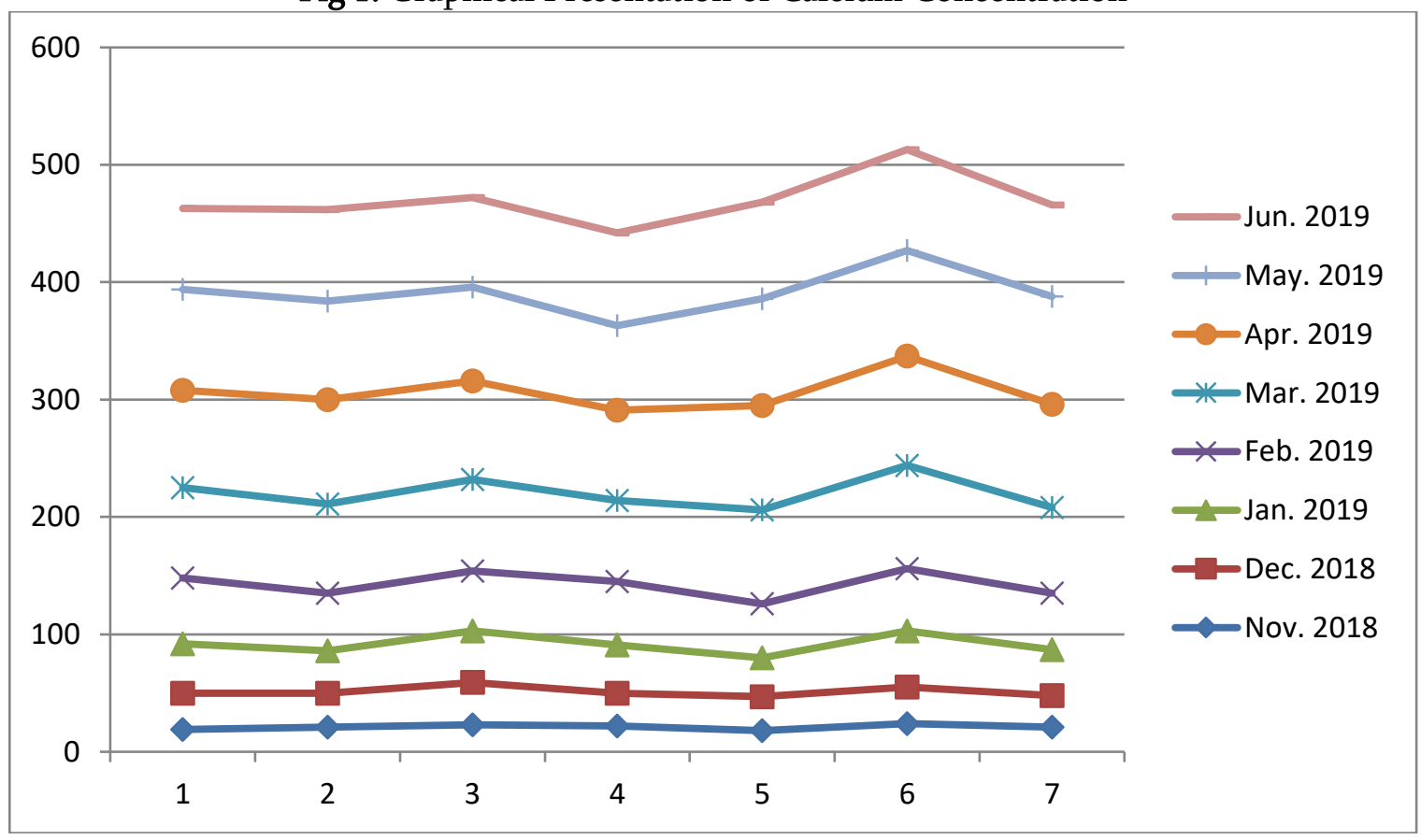


Fig 2. Stream Network Map of Nira River Basin

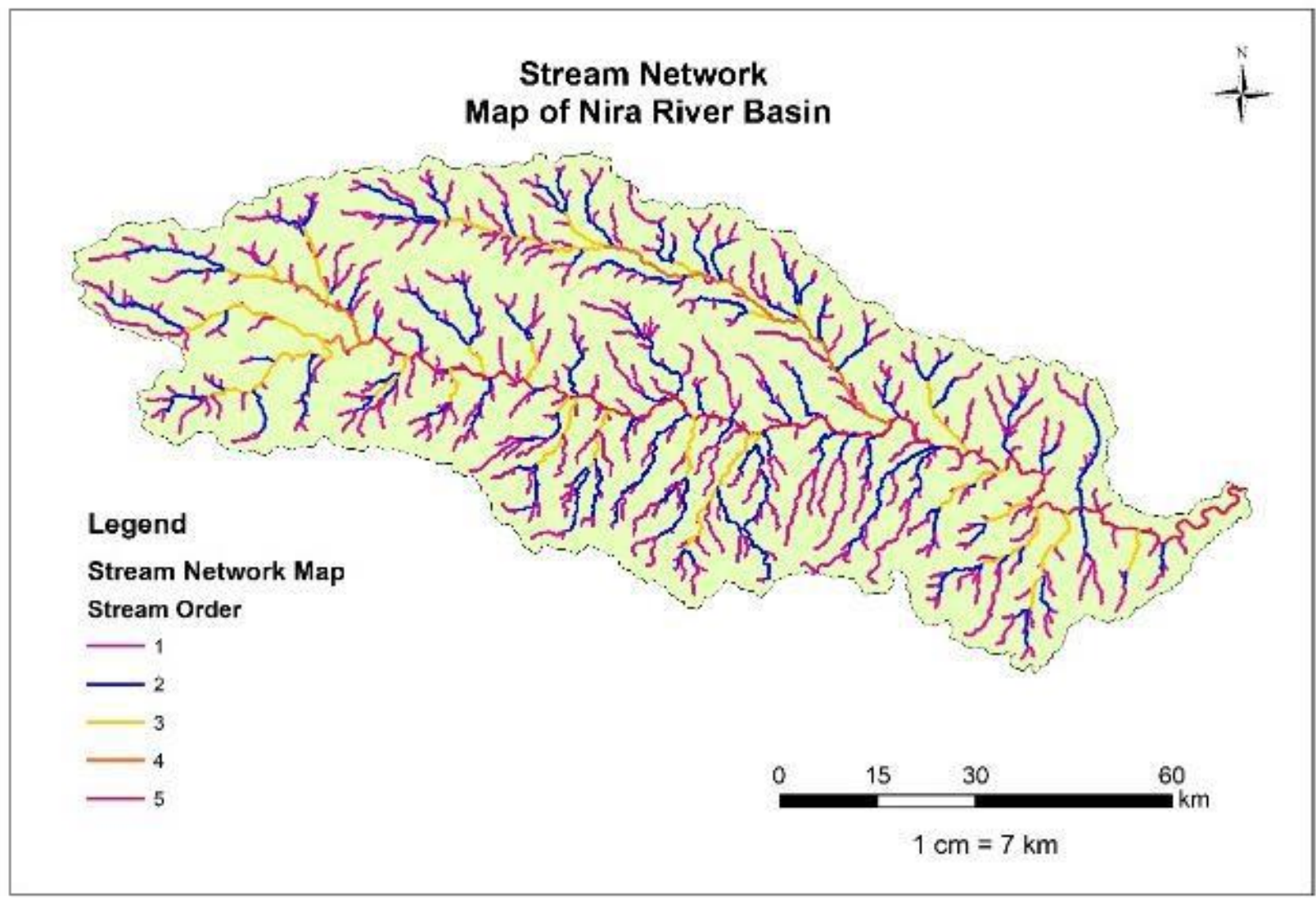

Fig 3. Neera River Flowing Water In Summer

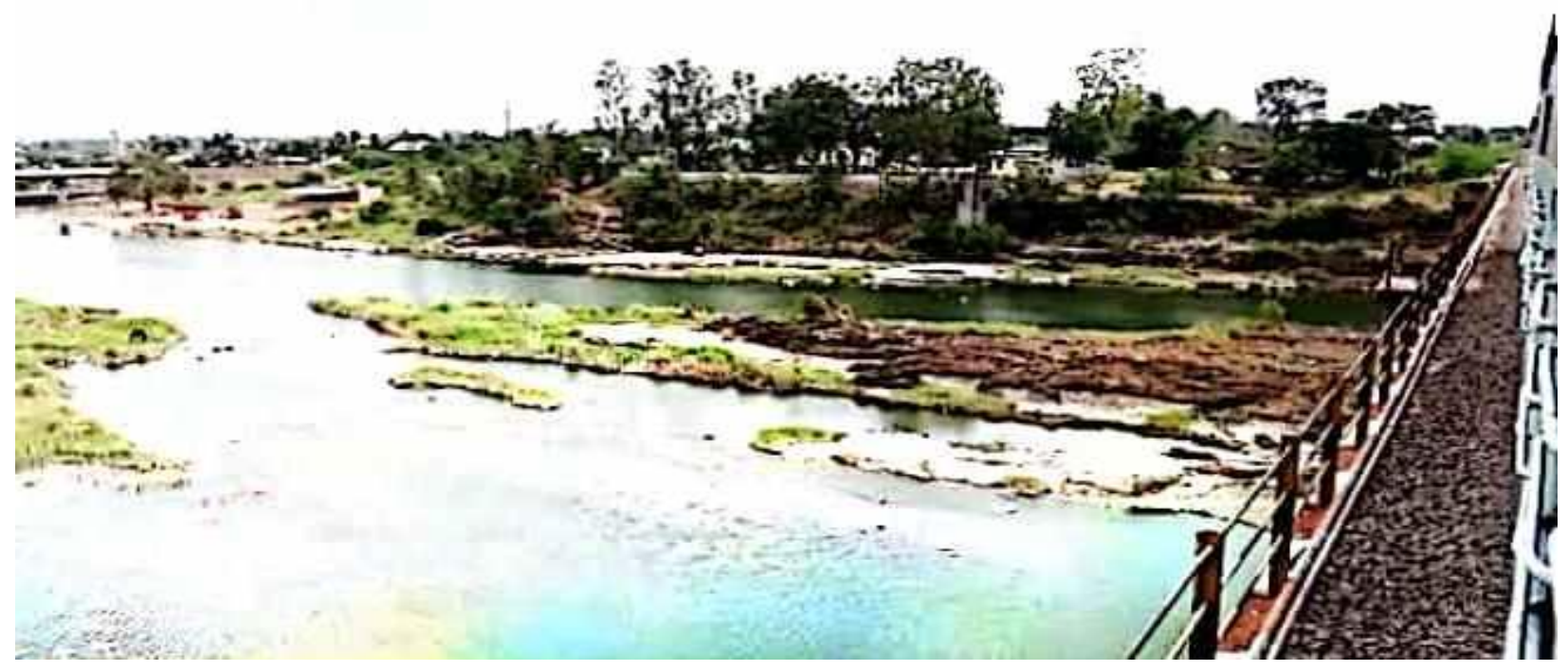

\section{RESULTS AND DISCUSSION}

Calcium and magnesium are the most abundant elements in the natural surface and groundwater and exist mainly as bicarbonates and to a lesser degree in the form of sulfate and chloride. Calcium concentration in present study ranges from minimum19.00 mg/l to maximum $93.00 \mathrm{mg} / \mathrm{l}$ in the 
river water. Its average value was higher in winter followed in the summer $(93 \mathrm{mg} / \mathrm{l})$. A similar pattern was observed by Chatterjee S.N, et al. (2014) while studying the physico-chemical properties of Ganga river in West Bengal, and Shukla Bramhanand and Upadhya Nidhi (2017) also found similar trend while studying physico-chemical and bacteriological characteristics of Bansagar lake, Shadol (M.P.). Higher calcium concentration in the study was found at sampling stations viz. 6, 7 and 5 respectively.

Increase in calcium concentration at these sampling stations may be due to human activities like bathing, washing cattle's, clothes and disposal of sewage as well as agricultural run-off into the river body(Varale Yashodhar, 2018, S. D. Jadhav \& et.al, 2017). The presence of calcium in water results, from passage through or over deposits of limestone, dolomite and gypsum. Small concentrations of calcium carbonate combat corrosion of metal pipes by laying down a protective coating (Williams, G.P. 1989). Appreciable calcium salts on the other hand precipitate on healing to form harmful scale in boilers, pipes and cooking utensils.

\section{IV.CONCLUSION}

Hence, the present study was concluded that river water of the study area was not polluted in respect to calcium concentration assessment, which require continuous monitoring and treatment process if the water is to be used for drinking purposes. Some steps and awareness programs must need to educate local villagers to safeguard the precious river and its surrounding.

\section{ACKNOWLEDGEMENT}

Authors are thankful to the university authorities for the necessary help and guidelines provided at the time of this work.

\section{REFERENCES}

[1]. APHA 1995 (American Public Health Association) Standard methods of examination of water and waste water 19th Edition, New York U.S.A.

[2]. Chatterjee S.N, et al. 2014, Physico-chemical properties and bacteriological examination of river Ganga in and around Howrah District, West Bengal, India. 4(1) 27-30.

[3]. Hussain MF, Ahmed I. 2002 Variability in physico-chemical parameters of Pachin river (Itanagar). Ind. J Environ Hlth. 44:329-336.

[4]. Jaya Kalita Gogoi, 2016 A Critical Assessment of Safe Drinking Water in Different Villages of Jorhat District of Assam. International Journal of Science and Research (IJSR), 5(8) : 18321836.

[5]. Joshi DM, Kumar A, Agrawal N. 2009 Assessment of the Irrigation Water Quality of River Ganga in Haridwar District India. J. Chem. 2(2):285-292.

[6]. Kamalkanth S, Muniyan M, and Christy ponni A.2012 Seasional variations in physic-chemical parameters at Tranquebar coastal Nagapattinam, Tamilnadu, India. 2(4) 203-207.

[7]. Katakwar M. 2014 Water quality and pollution status of Narmada River's Korni Tributary in Madhya Prades, Int. J of Che St. 2(2):1-9.

[8]. Khadse, G.K., Patni, P.M., Kelkar, P.S. and Devotta, S. 2008. Qualitative evaluation of Kanhan river and its tributaries flowing over central Indian plateau. Environmental Monitoring and Assessment, 147: 83-92.

[9]. Mushini Venkatesh Subba Rao \& et.al. 2012, Assessment of quality of drinking water at Srikurmam in Srikakulam District, Andrapradesh, India. International Research Journal of Environment Sciences, 1 (2) , 13-20.

[10]. Reddi Jhansilakshmi and E.U.B. 2014 Seasional Variations in Physico-Chemical Parameters of 
Groundwater in Bhimavaram, Andhra Pradesh India, International Journal of Engineering Research and Development, 10 : 58-65.

[11]. S.D.Jadhav \& et.al, 2017 A Critical Assessment of Safe Drinking Water of Krishna River in Satara District (Maharashtra), INDIA. International Journal of Research in Advent Technology, 5 : 2321-9637.

[12]. Shukla Bramhanand and Upadhya Nidhi, 2017 Studies of physicochemical and bacteriological characteristics of Bansagar Lake Shadol (M.P), 2(2), 45-50.

[13]. Sharma D. K., J. P. Jangir, C. P. S. Chandel and C. M. Gupta, 1988 J. Indian water works Association; 57.

[14]. S. D. Jadhav, M. S. Jadhav, and R. W. Jawale, 2013 Physico-Chemical and bacteriological analysis of Indrayani River Water at Alandi, Pune District (Maharashtra) India, International Journal of Scientific \& Engineering Research, vol. 4, issue 11, 19401949.

[15]. Singh, A.K. and Hasnain, S.I. 1999. Environmental geochemistry of Damodar river basin, east coast of India. Environmental Geology, 37(1-2): 124-136.

[16]. S. Upadhyay, 1998 Physico-chemical characteristics of the Mahanadi estuarine systems, east coast of India, Indian J. Mar. Sci, $17,19-23$.

[17]. Trivedi R.K \& Goel P.K. 1984 Chemical and biological methods for water pollution studies, Environmental Publ. Karad, India.

[18]. Varale Yashodhar, 2018 Calcium present in Tube Well Water Sample of Nipani town. International Journal of Science and Research (IJSR) 7(7).

[19]. V. P. Kudesia, 1985 Water pollution. Pragati Prakashan, Meerut.

[20]. Williams, G.P. 1989, Sediment concentrations versus water discharge during single hydrological events in rivers. Journal of Hydrology, III, 89-106.

[21]. World Health Organization (WHO), 2008 Guidelines for drinking water quality, Geneva WHO

\section{Cite this article as :}

S. D. Jadhav, M. S. Jadhav, "Study of Calcium Concentration of Neera River at Sarola Bridge Shirval, Pune, Maharashtra", International Journal of Scientific Research in Science and Technology (IJSRST), Online ISSN : 2395-602X, Print ISSN : 23956011, Volume 7 Issue 4, pp. 186-190, July-August 2020. Available at

doi $\quad$ : https://doi.org/10.32628/IJSRST207446

Journal URL : http://ijsrst.com/IJSRST207446 